\title{
Modeling water use for sustainable urban design
}

\author{
Ramesh Krishnamurti, Tajin Biswas, Tsung-Hsien Wang \\ School of Architecture, Carnegie Mellon University, \\ 5000 Forbes Avenue, Pittsburgh PA 15213, USA \\ \{ramesh, tajin, tsunghsw\}@cmu.edu
}

\begin{abstract}
Achieving sustainability on an urban scale is an overwhelming problem. We can address this by dividing the problem into manageable proportions. Environmental impacts of urban design fall into measurable categories, for example, air quality, biodiversity, solid wastes, water and wastewater, hazardous materials, and impacts of nonrenewable energy use. Such measures are incorporated into building rating systems as a way of codifying sustainability. In this chapter, to illustrate such codification, we examine water use as well as generated wastewater according to the requirements of a specific sustainable building rating system. Conventional calculations are coupled with building information modeling to illustrate the overall effects of parametrically selecting fixtures, systems and materials to control the use of potable water. We further demonstrate how this approach of combining parametric building information modeling with measures of their environmental impacts can be employed on an urban scale, thereby, guiding the design of sustainable urban spaces.
\end{abstract}

Keywords: Sustainability, Sustainable Building Rating System, Building Information Modeling, Parametric Modeling.

\section{Introduction}

In 2008 the number of urban dwellers surpassed those living in rural areas [1]. Cities and their residents occupy $2 \%$ of the terrestrial surface and consume large amounts $(75 \%)$ of the world's natural resources. While these resources are becoming scarcer, the nature of the use and waste of resources contribute to environmental degradation. Among the resources to run our cities-energy, water, building materials - are some that can be reasonably quantified. Water consumption reduction, water recycling, and wastewater minimization are supported by almost all sustainability principles that are codified by sustainable building rating systems.

Urbanization is growing at a staggering scale, according to census 2000 population statistics, almost $80 \%$ of the total world's population live in urban areas today [2], and approximately $44.2 \mathrm{bgal} /$ day of water withdrawals are used for public supply [3]. Rise in urban population shows an increase in the use of potable water from public supply from $62 \%$ in 1950 to $86 \%$ in 2005 . Increase of population further complicates, with the geographical shift of population requiring rapid increase in water supply demand and maintenance of aging systems in areas of diminishing populations. In the last twenty years, communities have spent $\$ 1$ trillion in 2001 dollars on drinking water 
treatment and supply, and wastewater treatment; although this is an staggering amount, it may not be sufficient for future needs [4].

Water conservation is more widely followed in the arid areas of the United States. However, using water efficiently is increasingly becoming an essential part of creating sustainable buildings and environment [5]. Ezel [6]cites a recent study by McGraw Hill's Construction [7], which indicates that after energy efficiency, water is treated with the next highest priority.

In order to study the effects of water use in the urban setting, we begin, firstly, by looking at water use in a residential building and then look at typical water use in commercial office buildings. According to Vickers [8], water use reduction in residences can be improved by efficiencies in water use, that is, by a combination of using less water with water efficient fixtures, and reusing wastewater generated by water use activities such as showers, baths, and laundry. Wastewater generated from bathtubs, wash basins, dishwashers and laundry is defined as graywater by the Uniform Plumbing Code (UPI) in its Appendix G [9]. Although graywater reuse strategies are being used for reducing overall water requirements, our focus in this chapter is to study water savings as a result of using water efficient fixtures and the possibilities for rainwater collection and reuse.

According to Mayer et. al. [10], toilets use $29 \%$ of total indoor water consumption. Water used for showering/bathing, dishwashing and laundry respectively account for about $36 \%, 14 \%$ and $21 \%$ of total indoor water consumption. In the case of the urban scenario, where we consider commercial office buildings, according to Dziegielewski [11], indoor water use falls into mainly three categories. These are: indoor use for toilets and wash basins, and cooling systems; and outdoor use for irrigation based on the landscape and types of plants.

In this research we focus on water used from the first category, which considers toilets, and wash basins. We construct an urban mass model around an office building by creating a building information model (BIM) and then implement an add-on application, where the effects of using efficient water fixtures can be easily visualized. It is important to point out that our original prototype application was primarily created for individual sustainable building projects-our aim is to expand its capabilities to meet needs at an urban scale.

\section{Background}

Environmental Aspects. The total water withdrawn for use in buildings for toilets, faucets and showerheads are from rivers, streams and underwater aquifers. Reducing the amount of water for these uses would benefit potable water conservation. Reduction in potable water means that less water would need to be treated at municipal water treatment works. The accumulated effects of water use reductions go as far as allowing municipalities to defer or keep up with high investments in wastewater treatment infrastructure and supply of clean water.

In the case of rainwater harvesting for systems for reduction of potable water use in flushing, local weather conditions as well as local health ordinances should be taken into account. Quality of water supplied from rainwater collection or recycled 
graywater have to be accounted for in the selection of fixtures to ensure long-term fixture performance.

Economic Aspects. Reduction of water consumption at the source helps to minimize the overall operating costs of a building. According to USGBC, buildings that have been retrofitted with more efficient plumbing fixtures through incentives programs provide a cost effective way of deferring capital costs of water treatment and supply facilities. The EPA estimates that public wastewater and supply infrastructure repair costs for the United States in the next 20 years will be about $\$ 745$ billion to $\$ 1$ trillion. Infrastructure repair and replacement costs to an already aging system will increase the cost average for water bills from $0.5 \%$ of the average household income to $0.9 \%$ [12]. Thus, water efficiency on a large scale will decrease the stress on current water management infrastructure such as water distribution networks, sewer lines, and treatment of both sewage and drinking water supplies.

Policy Aspects. Changing existing water fixtures with more efficient ones makes them more affordable; councils and organizations that promote green building rating systems have mobilized the industry to make efficient fixtures and water saving technologies more readily available in the general market. However, reusing graywater or harvested rainwater still has potential problems. For example, adequate filtration, treatment facilities and water tanks need to be considered during design.

\subsection{Rating Systems and Water Efficiency}

As a way of codifying sustainability, certain measures are incorporated in the form of green building rating systems. To illustrate, we examine the water use category from the perspective of four different rating systems. The rating systems shown correspond to those chosen by Fowler [13] as providing inherently distinct ways of calculating water as an important resource in the building domain. Although these rating systems set requirements for buildings, there are certain rating systems such as BREEAM that have started to expand their benchmarking to the community scale [14].

In Table 1, the left column captures the broad categories in which water resource use is measured. Water use reduction is considered as an essential measure in all the rating systems, this category is generally measured by the percentage of water use reduction. Two cases are compared: water use in a design, and a baseline water use. The LEED (Leadership in Energy and Environmental Design) rating system, developed by the US Green Building Council, has 4 credits alone dedicated to this criterion. Green Star of Australia awards from up to a maximum of 5 points for water use reduction. BREEAM (Building Research Establishments Environmental Assessment Method) allocates 3 credits, while Green Globes dedicates between 10-40 points depending on the amount of reduction in water use. Although different weights and points are given to this category by the different rating systems, all consider water use reduction as an essential component of green design. 
Table 1. Water efficiency requirements in different rating systems

\begin{tabular}{|c|c|c|c|c|}
\hline $\begin{array}{l}\text { Water } \\
\text { Efficiency }\end{array}$ & LEED 3.0 & Green Star & BREEAM & Green Globes \\
\hline $\begin{array}{l}\text { Water use } \\
\text { reduction }\end{array}$ & $\begin{array}{l}\text { WE pre, WE } 3.1- \\
3.3 \text { Water use } \\
\text { reduction by } \\
20 \%, 30 \%, 40 \% \text {, } \\
50 \%\end{array}$ & $\begin{array}{l}\text { Wat-1 Occupant } \\
\text { amenity water } \\
\text { (reduction of } \\
\text { water use) }\end{array}$ & $\begin{array}{l}\text { Wat-1 Water } \\
\text { consumption } \\
\text { reduction for } \\
\text { sanitary purposes }\end{array}$ & $\begin{array}{l}\text { D1. Water } \\
\text { consumption } \\
\text { reduction }\end{array}$ \\
\hline $\begin{array}{l}\text { Water } \\
\text { efficient } \\
\text { landscaping }\end{array}$ & $\begin{array}{l}\text { WE 2.1- } 2.2 \\
\text { Reduce water } \\
\text { use for irrigation }\end{array}$ & $\begin{array}{l}\text { Wat-3 } \\
\text { Landscape } \\
\text { irrigation }\end{array}$ & & $\begin{array}{l}\text { D 2.3 Minimal } \\
\text { use for irrigation } \\
\text { D2.4 Efficient } \\
\text { irrigation } \\
\text { equipment }\end{array}$ \\
\hline $\begin{array}{l}\text { Waste water } \\
\text { treatment }\end{array}$ & $\begin{array}{l}\text { WE } 2 \text { Innovative } \\
\text { waste water } \\
\text { technologies }\end{array}$ & & & $\begin{array}{l}\text { D3.1 Reduce } \\
\text { offsite water } \\
\text { treatment }\end{array}$ \\
\hline $\begin{array}{l}\text { Water use } \\
\text { control }\end{array}$ & & $\begin{array}{l}\text { Wat- } 2 \text { Water } \\
\text { meters }\end{array}$ & $\begin{array}{l}\text { Wat-2 Water } \\
\text { meter for } \\
\text { monitoring } \\
\text { consumption } \\
\text { Wat-3 Major } \\
\text { leak detection } \\
\text { Wat-4 Sanitary } \\
\text { supply shut off }\end{array}$ & $\begin{array}{l}\text { D2.1 Sub- } \\
\text { metering for high } \\
\text { use areas }\end{array}$ \\
\hline $\begin{array}{l}\text { Systems } \\
\text { water use }\end{array}$ & & $\begin{array}{l}\text { Wat-4 Heat } \\
\text { rejection water } \\
\text { Wat-5 Fire } \\
\text { system water use }\end{array}$ & & $\begin{array}{l}\text { D2.2 Minimal } \\
\text { use for cooling } \\
\text { towers }\end{array}$ \\
\hline
\end{tabular}

\subsection{Urban Water Use in Commercial Buildings}

Reducing water use by installing efficient fixtures is a relatively simple criteria to follow in order to earn credits, for example, from a sample of LEED 2.1 Silver certified buildings in Pennsylvania, we found that $88 \%$ of the buildings achieved credits for water use reduction, and $56 \%$ of the same set achieved 4 out of 5 possible credits [15]. Figure 1 shows the samples, numbered from 1 to 25 on the $\mathrm{x}$-axis, with the water efficiency credits on the y-axis, numbered from 1 to 5 . 


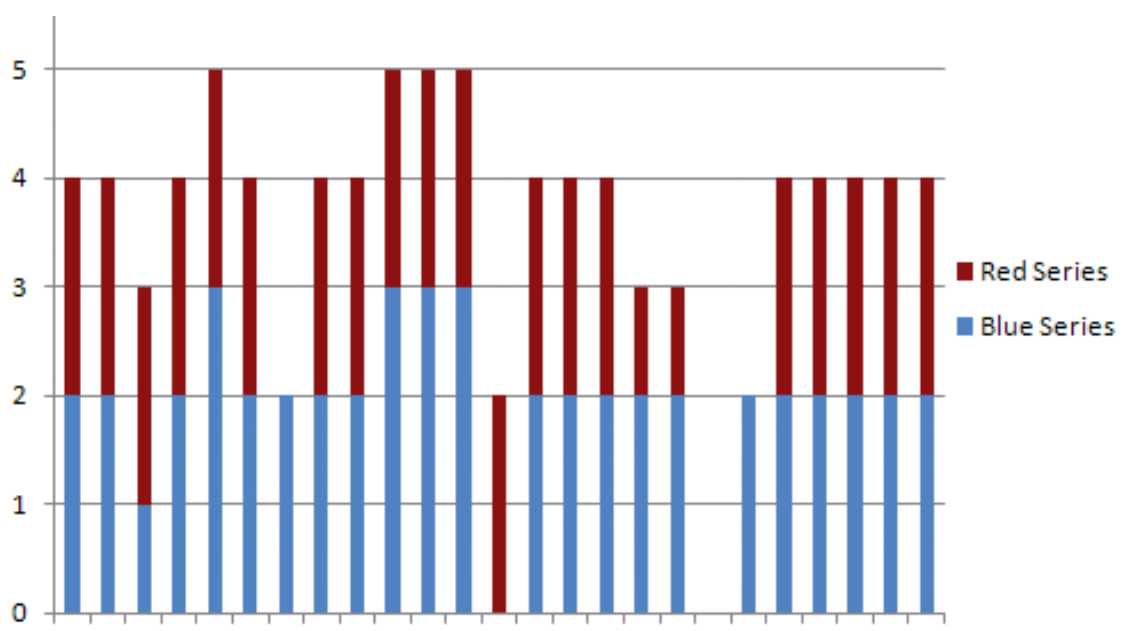

$122 \quad 3 \quad 4 \quad 5 \quad 6 \quad 7 \quad 8 \quad 9 \quad 10111213141516171819202122232425$

Fig. 1. Distribution of LEED water credits earned by certified buildings. The blue series represents credits WE 1.1, WE 1.2 and WE 2, while the red series represents credits WE 3.1 and WE 3.2. These two kinds of credits essentially cover fixtures, uses and calculations for water use loads for a building.

Taking a close look at LEED certified buildings on the campus of Carnegie Mellon University, we found that all but one had acquired water reduction credits (Table 2). According to facilities management, the benefits can be seen not only in the use of less water but also in the overall operation and maintenance costs of the facilities. It should be noted that although there are different types of buildings certified under LEED New Construction, calculations generally differ only in the allocation of types of fixtures, number of users and number of days in a year the buildings are used. The reason for the one building where LEED water credits were not achieved can be attributed to small area of the building. Water use reduction is reflected in the deployment of available efficient fixtures at the time.

Table 2. Water Efficiency credits achieved for LEED certified buildings on the campus of Carnegie Mellon University

\begin{tabular}{|l|l|l|l|}
\hline Project Name & Certification & LEED version & LEED water credits achieved \\
\hline New House & Silver & LEED NC 2.0 & WE 1.1, WE 1.2 \\
\hline Henderson House & Silver & LEED NC 2.0 & $\begin{array}{l}\text { WE1.1, WE 1.2, WE3.1, } \\
\text { WE3.2 }\end{array}$ \\
\hline 407 S Craig St & Silver & LEED NC 2.1 & None \\
\hline 300 S Craig St & Silver & LEED NC 2.1 & WE1.1, WE 1.2, WE 3.1 \\
\hline $\begin{array}{l}\text { Collaborative } \\
\text { Information Center }\end{array}$ & Gold & LEED CS & $\begin{array}{l}\text { WE1.1, WE 1.2, WE2, WE 3.1, } \\
\text { WE 3.2 }\end{array}$ \\
\hline
\end{tabular}




\section{Modeling Water Use}

We employ two different methods to model water use in buildings. The first considers individual buildings to determine their water use. It is assumed that the number of occupants is known. Further, there is an urban information model containing the floor areas and numbers of floors in each building. Urban water use is then, an aggregation of water use by the occupants in each the selected buildings. The second approach works from 2D drawing of an urban area with known building heights. Numbers of occupants, fixtures and fixture flow rates are assigned and maintained in an external database. Figure 2 illustrates the test case, modeled in Revit ${ }^{\circledR}$ Architecture 2010 [16].

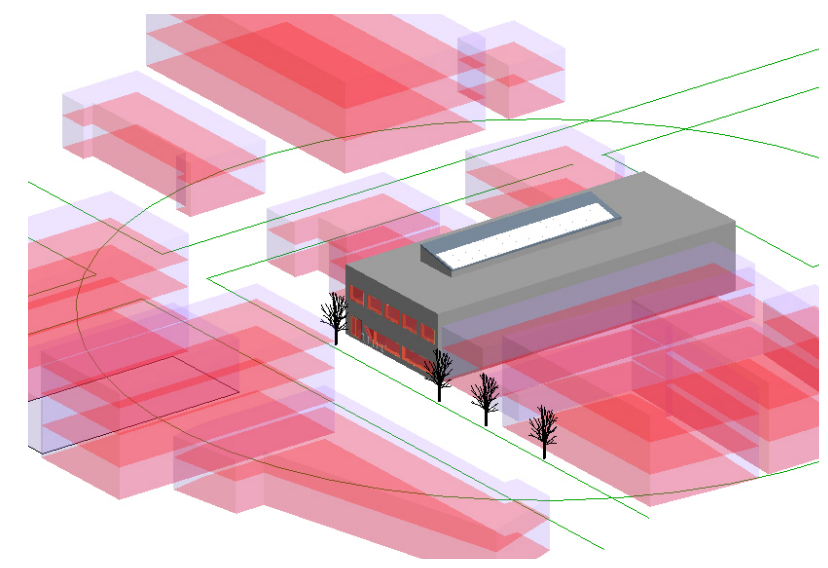

Fig. 2. Test case for modeling water efficiency for LEED

We employ criteria from LEED NCv2.2 for water use requirements and a building information model (BIM) to make informed decisions on using certain fixtures for achieving sustainability goals set by LEED. The advantage in creating and using a building information model is its intrinsic characteristic of holding project information for all team members. This includes designers, planners, facility managers, and on a larger scale, policy and decision makers. To demonstrate the approach of designing towards specific LEED goals, we use Revit Architecture 2010 as the building information model. As a commercial BIM, Revit offers capabilities for ready documentation and calculation that can be, ultimately, submitted for certification. Figure 3 shows a family of fixtures with essential information pertaining to water use calculation such as flow rate.

Calculations principally follow the LEED method for water use calculation outlined below. Water use reduction for a building/project corresponds to the difference between the design case and a baseline case. In this methodology water use is calculated by estimating occupant usage and fixture flow rates. Occupants are determined by calculating full time equivalent (FTE) occupancy of a building, which is based on a standard 8-hour occupancy period, thus, resulting in a value based on the hours per day divided by 8 . In the case of transient building populations such as students, visitors, or customers, hours are estimated for a representative daily average. 


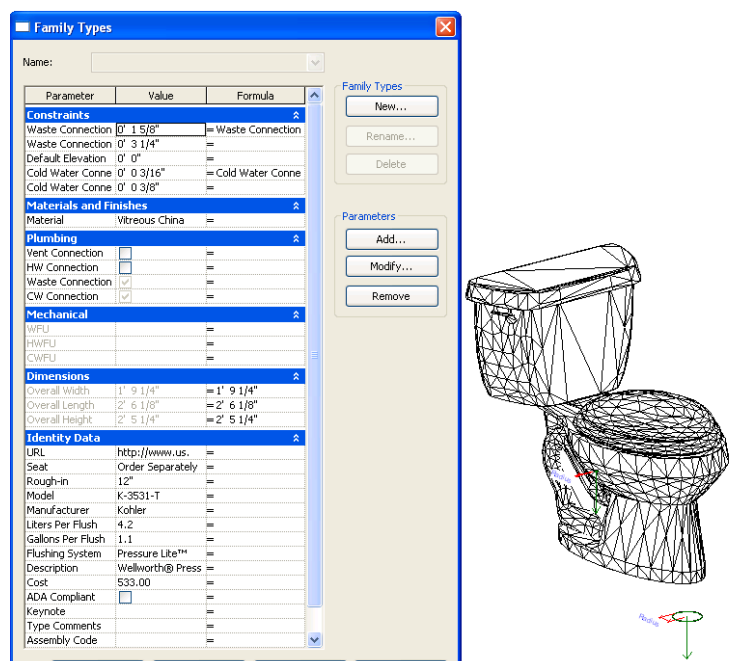

Fig. 3. Fixture information related to water use

Design Case. Annual water use is obtained by totaling the annual volume of water use by each fixture type and then, subtracting rainwater or graywater reuse. Actual flow rates and flush volumes for the installed fixtures are used in the calculation. For consistency, a balanced one-to-one ratio of male and female is assumed. Table 3 shows an example of a design case study for water usage from interior fixtures.

Table 3. Water use calculation based on flush and flow fixtures from a sample case study

\begin{tabular}{|l|c|c|c|c|r|}
\hline Fixtures & Daily use & Flowrate & Duration & Occupant & $\mathbf{H}_{\mathbf{2}} \mathbf{O}$ use \\
\hline Flush Fixture & & $G P F$ & (flushes) & (gal) & 0 \\
\hline Ultra Low Flow WC (m) & 0 & 0.8 & 1 & 80 & 192 \\
\hline Ultra Low Flow WC (f) & 3 & 0.8 & 1 & 80 & 0 \\
\hline Composting Toilet (m) & 1 & 0 & 1 & 80 & 0 \\
\hline Composting Toilet (f) & 0 & 0 & 1 & 80 & 0 \\
\hline Waterless Urinal (m) & 2 & 0 & 1 & 80 & 0 \\
\hline Waterless Urinal (f) & 0 & 0 & 1 & 80 & 240 \\
\hline Flow Fixture & & $G P M$ & (minutes) & & 80 \\
\hline Conventional Lavatory & 3 & 2.5 & 0.20 & 160 & 200 \\
\hline Kitchen sink & 1 & 2.5 & 0.2 & 160 & 712 \\
\hline Shower & 0.1 & 2.5 & 5 & 160 & 260 \\
\hline \multicolumn{5}{|r|}{} \\
\hline
\end{tabular}


Baseline Case. According to LEED methods, to create a baseline case, the design case table is used to provide the number of male and female occupants, with fixture flush and flow rate values adjusted as per EPAct default specifications [9]. Table 4 shows the baseline case for the same design case study.

Table 4. Baseline calculations for the same case study

\begin{tabular}{|c|c|c|c|c|c|}
\hline Fixtures & Daily use & Flowrate & Duration & Occupant & $\mathrm{H}_{2} \mathrm{O}$ use \\
\hline Flush Fixture & & $G P F$ & (flushes) & (gal) & \\
\hline Conventional WC (m) & 1 & 1.6 & 1 & 80 & 128 \\
\hline Conventional WC (f) & 3 & 1.6 & 1 & 80 & 384 \\
\hline Conventional Urinal (m) & 2 & 1 & 1 & 80 & 160 \\
\hline Conventional Urinal (f) & 0 & 0 & 1 & 80 & 0 \\
\hline Flow Fixture & & $G P M$ & (minutes) & & \\
\hline Conventional Lavatory & 3 & 2.5 & 0.25 & 160 & 300 \\
\hline Kitchen sink & 1 & 2.5 & 0.25 & 160 & 100 \\
\hline Shower & 0.1 & 2.5 & 5 & 160 & 200 \\
\hline \multicolumn{5}{|c|}{ Total Volume (gal) } & 1272 \\
\hline \multicolumn{5}{|r|}{ Work days } & 260 \\
\hline \multicolumn{5}{|c|}{ Annual volume } & 330720 \\
\hline \multicolumn{5}{|c|}{ Rain water or graywater reuse } & 0 \\
\hline \multicolumn{5}{|c|}{ Annual water use (gal) } & 330,720 \\
\hline
\end{tabular}

Water use calculations are straightforward. However, this can be problematical, because of missing data as a result of integrating requirements from a rating system with a particular building information model. A model is only as complete as the information entered. Pertinent information for water use calculations include occupant numbers, fixture costs and materials, which a designer must enter. Other required information external to any project in any building information model include rainfall data, plant water use data, etc. Such information is not expected to fall directly into the designer's purview, yet these factors have to be accounted for. Table 5 shows the required objects for calculating LEED NC 3.0 water related credits.

Water fixtures are components stored in the Revit library. As stored, when queried, only dimensions of instances are returned. Dimensions are incorporated into the object names; there is no other way of getting at object parameters, or other needed material properties from the objects, unless the information from manufactures specifications has been filled as shown in Figure 3.

To calculate Water Efficiency credits, we implemented external databases for fixtures and landscapes. In the prototype shown in Figure 4 there are two tabs under the Water Efficiency category. These contain the necessary tasks to be fulfilled when evaluating water efficiency credits. 


\begin{tabular}{|c|c|c|c|c|c|c|}
\hline 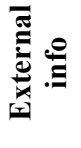 & & & 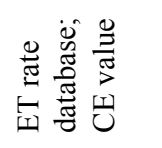 & & & \\
\hline 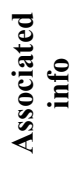 & 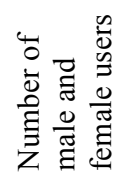 & & 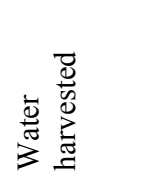 & 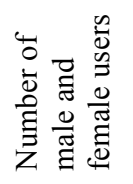 & 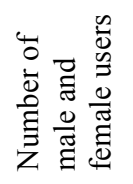 & 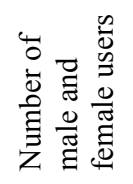 \\
\hline 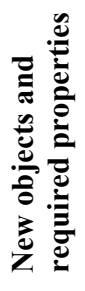 & & 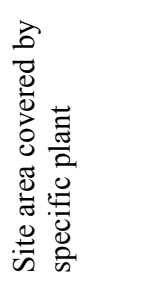 & 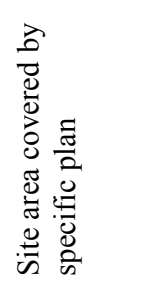 & 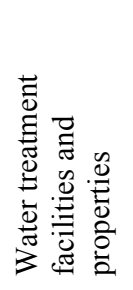 & & \\
\hline 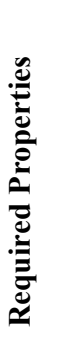 & 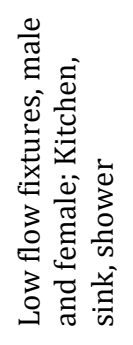 & 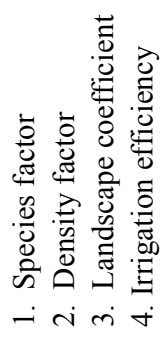 & 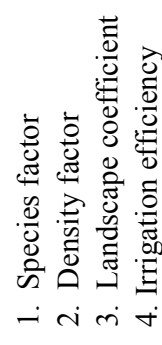 & 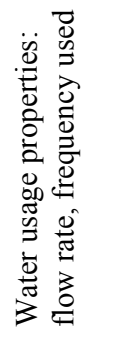 & 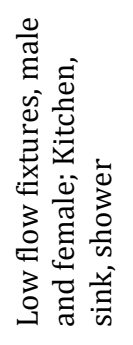 & 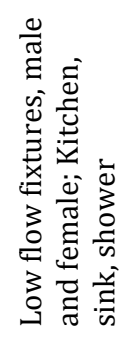 \\
\hline 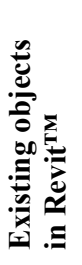 & 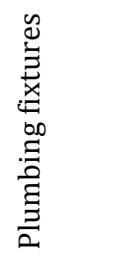 & $\frac{\vec{E}}{\stackrel{\vec{E}}{a}}$ & $\frac{\vec{U}}{\frac{\vec{U}}{2}}$ & 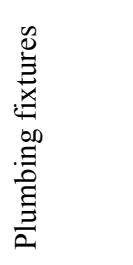 & 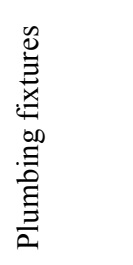 & 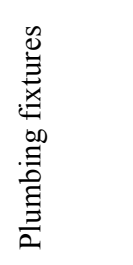 \\
\hline 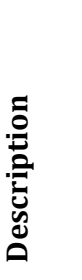 & 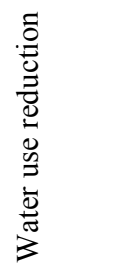 & 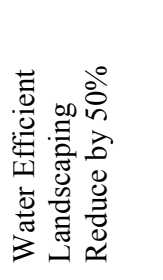 & 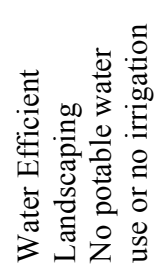 & 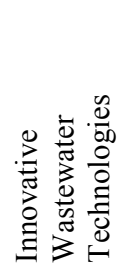 & 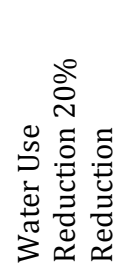 & 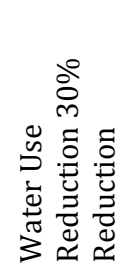 \\
\hline 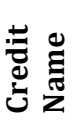 & 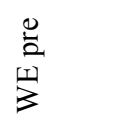 & 굴 & $\begin{array}{l}\text { N } \\
\underset{5}{\text { II }} \\
3\end{array}$ & $\stackrel{N}{y}$ & $\begin{array}{l}\vec{n} \\
\dot{m} \\
\dot{y} \\
3\end{array}$ & $\begin{array}{l}\stackrel{N}{m} \\
\stackrel{\omega}{\Gamma} \\
3\end{array}$ \\
\hline
\end{tabular}




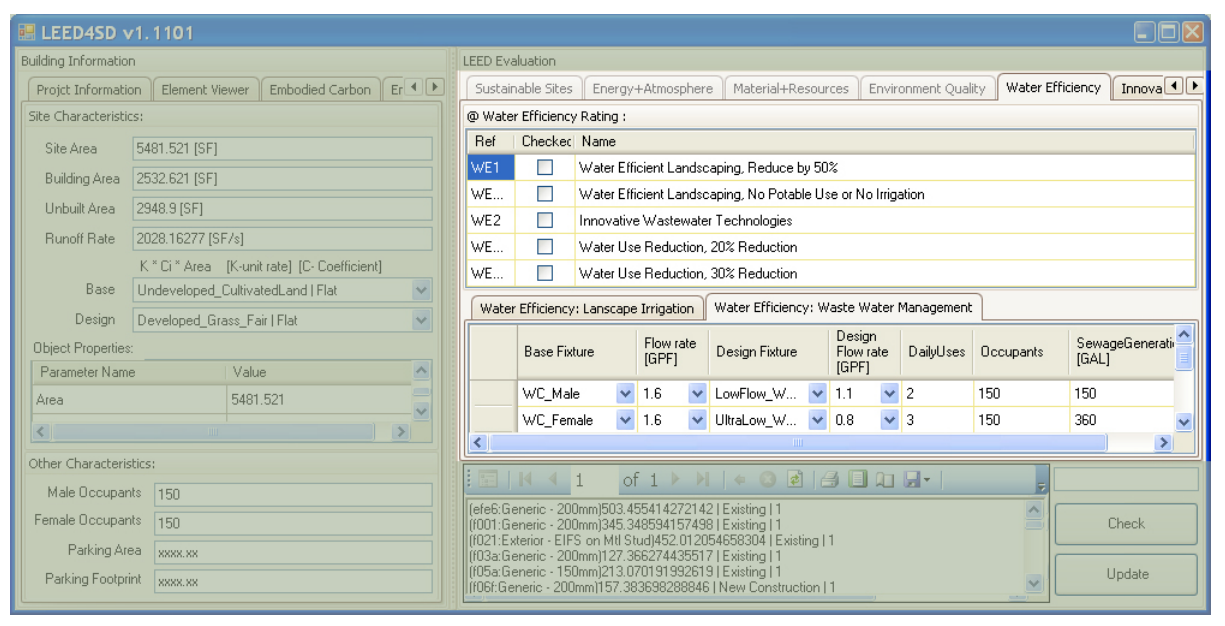

Fig. 4. Water efficiency tabs for rating credits, and various water related calculations

The overall workflow for wastewater management, firstly, retrieves information about the numbers of male and female occupants, which are specified in the building information section of the building information model (Revit). Differences between the baseline and design cases are then compared to determine the number of credits that are earned at this stage.

Most building information models, including Revit, usually offer capabilities for calculating the area covered by buildings, site area, but ground cover type typically has to be manually specified. Although the model can be detailed with material type, information retrieved mostly relates to size and graphics. Additional materials and object parameters such as porosity for materials and flow rates for fixtures are needed. Cost values for fixtures from manufacturers are used for comparison in water use and ultimate cost savings.

The prototype was implemented as an add-on to Revit Architecture 2010. It collects information from the fixtures placed in the model and calculates credits according to methods set out by LEED and the other standards. The application has the potential to be extended to accumulate information from multiple buildings and aggregate total water use. This approach, however, would work only when all pertinent information is available.

\subsection{Modeling Urban Water Use}

Size matters when there is a shift in scale from the unit to a community. At the urban scale, we face the challenge of propagating results from one building to many. In this study we assume that the buildings are commercial office buildings.

Assumptions and Challenges. In modeling for water use on a larger scale, we have far less information. Here, we adopt a slightly different approach, and employ a combination of different commercial software. The parameters that affect water use 
are similar to those seen in Tables 3 and 4. At this stage, graywater quantity and rainwater harvesting is not accounted for in the calculation.

As there are many buildings, assigning users to each individual building is difficult owing to lack of information; in this case, we have adopted the method of assigning occupants used by Green Star's method for space allocation [17].

Urban Case Study. The sample case study covers an area of $17346.85 \mathrm{~m}^{2}$. Of this total area, $11706.56 \mathrm{~m}^{2}$ covers the building footprint; the remainder comprises roads, pavements and parking areas, which are assumed to have an impervious ground cover. There are also open spaces, which have potential for planning for rainwater catchments and water management. The model is generated from a $2 \mathrm{D}$ CAD drawing, and converted into a mass model for the purpose of calculating the total floor areas of buildings. Figure 5 shows the CAD drawing of a portion of the urban area modeled.

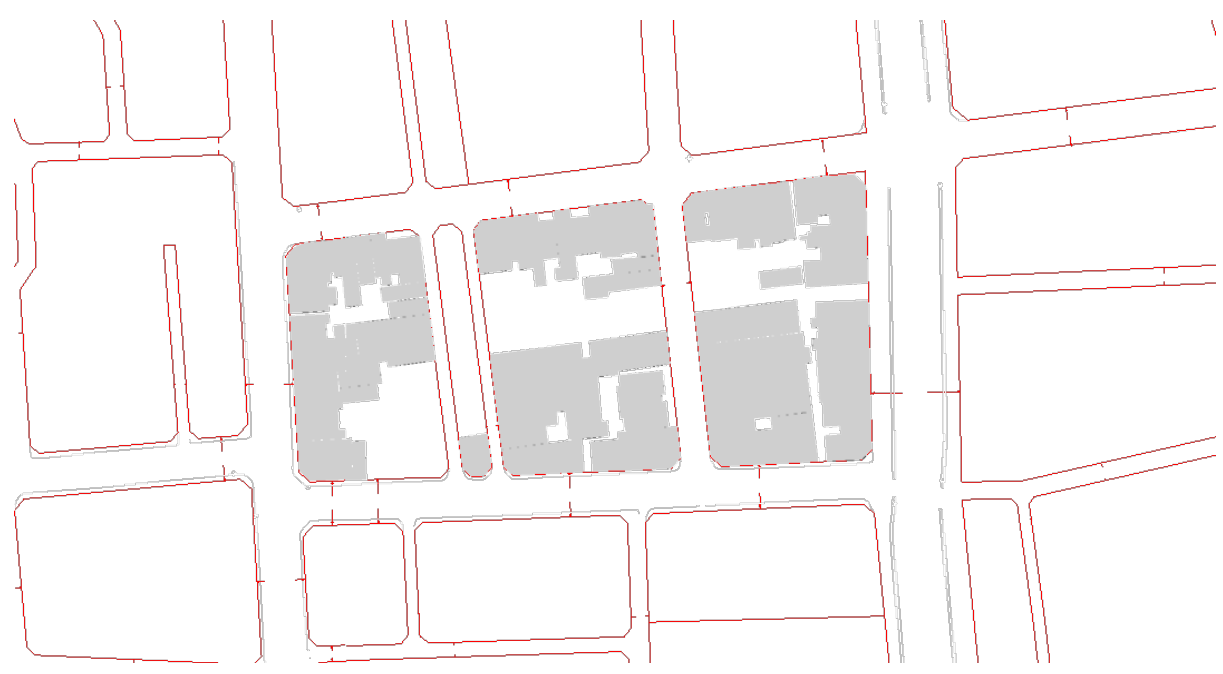

Fig. 5. CAD drawing of the test urban area

To generate the three dimensional model we used Rhinocerous ${ }^{\circledR}$ [18] with Grasshopper $^{\mathrm{TM}}$ [19]. This offers an easy way to generate a parametric model with the facility to calculate total floor areas for the buildings and specify occupants, fixtures and parameters for calculating water use on a larger scale, with greater flexibility than the Revit environment can currently afford at this juncture. As both Rhino3d and Revit are built on top of the .NET framework [20], communicating specific information between software is fairly straightforward. Figure 6 shows the mass model generated through Grasshopper in Rhino3d. The grasshopper definition file in Figure 7 shows the connection between model geometries to external databases that contain fixture information to generate the water use model for the urban area.

As the scale changes from building to urban, we begin to notice that water use reduction is only a piece of the overall water management scheme. The model reveals 
potential spaces for artful rainwater catchment areas [21]. Rainwater management, collection and reuse in buildings, and for community activities, rely not only on individual buildings and their storm water collection strategies, but also become part of urban planning, as this is not always cost effective to do so for smaller projects. Information for groundcover type, vegetation, rainfall data for the area are critical to calculating rainwater runoff and collection potential. This is information that is not originally part of the building information model; however, such data needs to be supplied whether calculations are done either in Revit or Rhino3d, or some other combination of commercial building/urban information models.

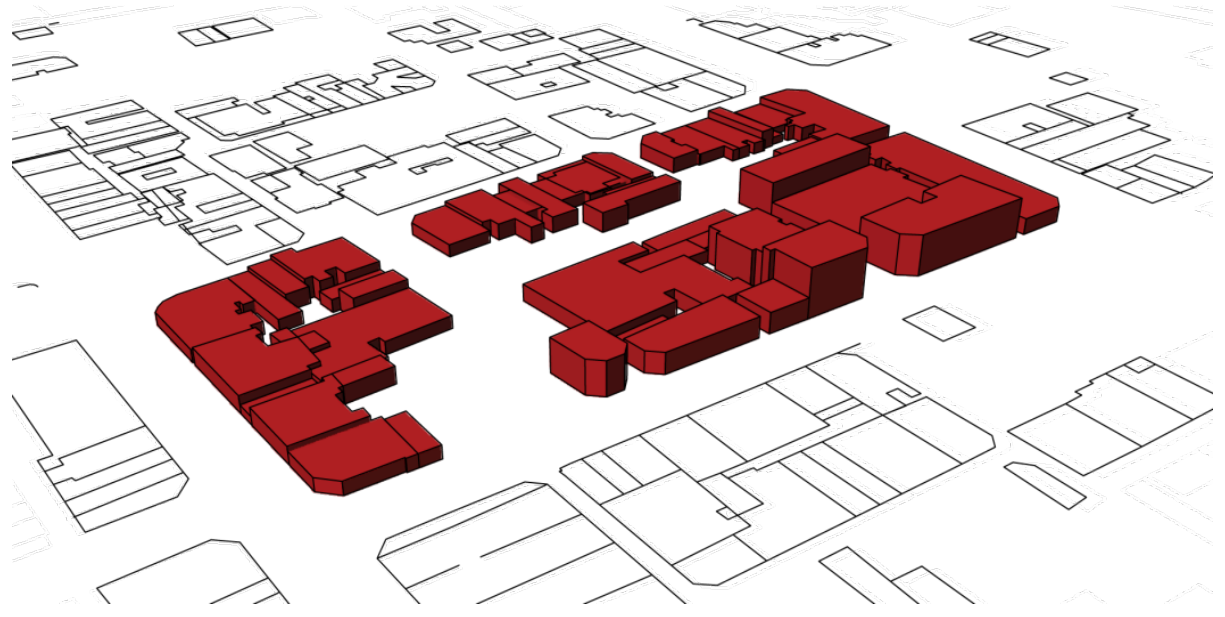

Fig. 6. Modeling the urban area

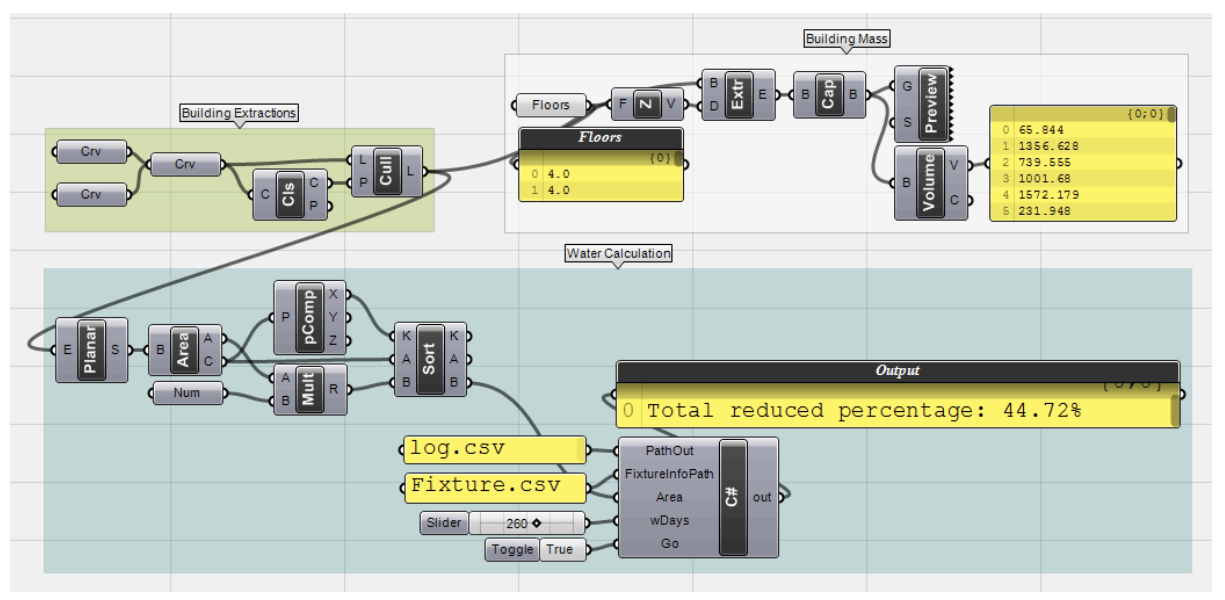

Fig. 7. Grasshopper definition file for water use model generation 


\section{Analysis}

Our sample model for urban water use considered a total building area of $52439 \mathrm{~m}^{2}$ and 3516 occupants. By changing design cases we were able to see explore variations in water use reduction rates. Tables 6 and 7 depict a portion of the sample urban area. For both design cases the number of uses of the fixtures was the same and distribution of male and female were evenly balanced at a ratio of $1: 1$.

Table 6. Water use reduction: design case 1

\begin{tabular}{|l|l|c|c|c|}
\hline Building No. & Case 1 & Area (m^2) & Occupant & Water Use \\
\hline Building_000 & BASE & 1174.0848 & 79 & 617247.540 \\
\hline Building_000 & DESIGN & 1174.0848 & 79 & 340844.868 \\
\hline Building_001 & BASE & 1356.6284 & 91 & 711006.660 \\
\hline Building_001 & DESIGN & 1356.6284 & 91 & 392618.772 \\
\hline Building_002 & BASE & 153.9494 & 11 & 85945.860 \\
\hline Building_002 & DESIGN & 153.9494 & 11 & 47459.412 \\
\hline Building_003 & BASE & 1001.68 & 67 & 523488.420 \\
\hline Building_003 & DESIGN & 1001.68 & 67 & 289070.964 \\
\hline Building_004 & BASE & 739.5551 & 50 & 390663.000 \\
\hline Building_004 & DESIGN & 739.5551 & 50 & 215724.600 \\
\hline Building_005 & BASE & 65.8443 & 5 & 39066.300 \\
\hline Building_005 & DESIGN & 65.8443 & 5 & 21572.460 \\
\hline & \multicolumn{5}{|c}{ Total reduced percentage } & $44.78 \%$ \\
\hline
\end{tabular}

Table 7. Water use reduction: design case 2

\begin{tabular}{|l|l|c|c|c|}
\hline Building No. & Case 1 & Area $\left(\mathbf{m}^{\wedge} \mathbf{2}\right)$ & Occupant & Water Use \\
\hline Building_000 & BASE & 1174.0848 & 79 & 617247.54 \\
\hline Building_000 & DESIGN & 1174.0848 & 79 & 298918.62 \\
\hline Building_001 & BASE & 1356.6284 & 91 & 711006.66 \\
\hline Building_001 & DESIGN & 1356.6284 & 91 & 344323.98 \\
\hline Building_002 & BASE & 153.9494 & 11 & 85945.86 \\
\hline Building_002 & DESIGN & 153.9494 & 11 & 41621.58 \\
\hline Building_003 & BASE & 1001.68 & 67 & 523488.42 \\
\hline Building_003 & DESIGN & 1001.68 & 67 & 253513.26 \\
\hline Building_004 & BASE & 739.5551 & 50 & 390663 \\
\hline Building_004 & DESIGN & 739.5551 & 50 & 189189 \\
\hline Building_005 & BASE & 65.8443 & 5 & 39066.3 \\
\hline Building_005 & DESIGN & 65.8443 & 5 & 18918.9 \\
\hline & \multicolumn{5}{|c|}{ Total reduced percentage } & $51.57 \%$ \\
\hline
\end{tabular}


With the tool it is possible to vary the number and type of fixtures, change the ratio of male and female occupants, and also allocate different design cases to different parts of the urban area in order to parametrically model various scenarios for water use. The two design cases shown have different fixture flow rates; the resulting water reduction savings for design case 1 is $44.78 \%$, and $51.57 \%$ for design case 2 . Case 1 also has a savings of 12.3 million liters of potable water annually.

\section{Conclusions}

We have hinted at a fraction of possible calculations that stem from combining a rating system requirement (in this case, LEED) with capabilities provided by a specific commercial building information model (in this case, Revit). We have also given an alternate approach, based on a combination of commercial software, that is, Grasshopper and Rhino3d, external databases and rating system requirements, to illustrate how information (in this case, for modeling water use) can be gathered and processed on a larger scale. These methods can be used to both pre-certify a building for sustainability, and on a larger scale, to project the effects on environmental resources. Through the use of different parameters, generally simple calculations, and by augmenting extant databases of materials and objects, we show how current commercial tools can be used to model environmental resources at both the building and urban scales. There is also no technical reason to suppose that the approach will not work with other green rating system requirements, other commercial building information models and software, or for other environmental resource related calculations. The approach outlined here, to modeling urban water use, prepares the groundwork for implementing other water resource management tools, for example, for graywater and rainwater collection, design of green roofs and water runoff calculation from different surfaces.

The findings described in this chapter lead to the conclusion that strategies, which focus on water use reduction from the scope of the individual building to the urban scale, are among the components required for water management that have to be cohesively integrated to create a 'Green Urbanism' [22].

Acknowledgments. This work reported in this chapter is an extension of a project on integrating building information models and rating systems funded by Autodesk ${ }^{\circledR}$, which aims to bringing sustainability principles closer to design. However, any opinions, findings, conclusions or recommendations presented in this chapter are those of the authors and do not necessarily reflect the views of Autodesk ${ }^{\circledR}$. We would like to thank the facilities department at Carnegie Mellon University for their assistance in providing us data and insights on strategies used for achieving credits in the water reduction category though the LEED rating system.

\section{References}

1. UNEP.: Cities and Green Buildings. (2009)

2. US Department of Transportion, http://www.fhwa.dot.gov/planning/census/cps2k.htm 
3. US Geological Survey, http://pubs.usgs.gov/circ/1344/

4. EPA, http://www.epa.gov/owm/gapreport.pdf

5. Xing, W., Akinci, B., Davidson, C.: Modeling Graywater on Residences. Journal of Green Building. vol 2. (2), pp 111-120.(2007)

6. Ezel, C., http://www.globalwarmingisreal.com/blog/2009/06/23/water-use-incommerical-buildings-where-does-it-all-go/

7. McGraw Hill Construction, http://construction.ecnext.com/coms2/summary_0249 307522_ITM_analytics

8. Vickers, A.: Handbook of Water Use and Conservation. Waterplow Press. Amherst, Mass. (2001)

9. USGBC.: New Construction and Major Rennovation Reference Guide. USGBC. Washington, DC. (2006)

10.Mayer, P.W., DeOreo W.B, Optiz, E.M., Kiefer J.C., Davis, W.Y., Dziegielewski, B., Nelson O.J.: Residential End Users of Water. AWWA Research Foundation and American Water Works Association. Denver, CO. (1999)

11.Dziegielewski, B.: Commercial and Institutional End Users of Water. AWWA Research Foundation and American Water Works Association. Denver, CO. (1999)

12.Congressional Budget Office, http://www.cbo.gov/publications/bysubject.cfm?cat=19

13.Fowler, K.R.: Sustainable Building Rating Systems Summary. Pacific Northwest National Laboratory, Department of Energy. (2007)

14.BREEAM, http://www.breeam.org/page.jsp?id=117

15.USGBC,

http://www.usgbc.org/LEED/Project/CertifiedProjectList.aspx?CMSPageID=247

16.Autodesk, http://usa.autodesk.com/

17.Green Building Council Australia, http://www.gbca.org.au/green-star/ratingtools/green-star-office-design-v3-green-star-office-as-built-v3/1710.htm

18.Rhinocerous, http://www.rhino3d.com/

19.Grasshopper, http://www.grasshopper3 d.com/

20.Microsoft, http://www .microsoft.com/NET/

21.Echols, S.: Artful Rainwater Design in the Urban Landscape. Journal of Green Building. vol 2. (4), pp 151-170. (2007)

22.Lehmann, S.: Sustainability on the Urban Scale:'Green Urbanism'-Mark II. Journal of Green Building. vol 2.(3), pp 61-78. (2007) 